\title{
The Effects of Reduced Beam Section on Castellated Beam
}

\author{
Nini H Aswad ${ }^{1 *}$, Herman Parung ${ }^{2}$, Rita Irmawaty ${ }^{3}$ and A Arwin Amiruddin ${ }^{3}$ \\ ${ }^{1}$ Doctoral student, Civil Engineering Department, Hasanuddin University, Makassar, \\ Indonesia \\ ${ }^{2}$ Professor, Civil Engineering Department, Hasanuddin University, Makassar, Indonesia \\ ${ }^{3}$ Associated Professor, Civil Engineering Department, Hasanuddin University, Makassar, \\ Indonesia
}

\begin{abstract}
This paper presents reduced beam section (RBS) technique on castellated beam. Aim of this study is to ensure the plastic moment reach far from column face without significant of strength decreasing. Four models of castellated beam with various types of RBS and one model without RBS have been considered. ABAQUS FEA software package was used for modelling purpose. Loading condition, i.e. lateral load as representing earthquake load, was monotonic load using displacement control at the top of the column. The result shows that the maximum load and the maximum displacement with RBS and without RBS do not portray significant difference. The maximum load RBS castellated beam and without RBS were respectively $86.17 \mathrm{kN}$ and $80.63 \mathrm{kN}$. It is indicated that the RBS on castellated beam might share relatively similar maximum load compared to non RBS castellated beam and the RBS can secure the stress concentration and plastic moment, the location of which is far from the column face. The reduced beam section (RBS) is put on beam-to-column moment connected on castellated beam.
\end{abstract}

\section{Introduction}

The various number of research activities has been conducted on the behavior of fully restrained steel connections in light of the 1994 Northridge earthquake, which some has emphasized on the Reduced Beam Section (RBS) moment connection. As regards the castellated beam connection, the RBS is denoted by a circular radius cut in both top and bottom flanges to reduce the flange area and consequently, the plastic moment capacity over a length of the beam near the ends of the beam span.

\footnotetext{
* Corresponding author : niniaswad@gmail.com
} 
This connection was developed to assure greater reliability of steel beam-to-column connections. The joint should have adequate strength and stiffness to resist the internal force induced by the framing members and external force like earthquake and wind loading, and moreover, the castellated model behaved softer therefore dissipate more energy than normal plate beam (Vahid et.al, 2013). The experimental and numerical results observed that cyclic performance of the RBS moment connection was much superior to the connection without RBS (Swati \& Gaurang, 2014). In an effort to gain additional insight into the behaviour of the tested specimens, this research investigates castellated beam reduced beam section (RBS) moment connection models by performing simulation on the computer program ABAQUS.

\subsection{Material properties and Sections}

In this study, profile of the beam is IWF 15075 with hexagonal castellated beam following the standardized dimension as shown on figure 1.
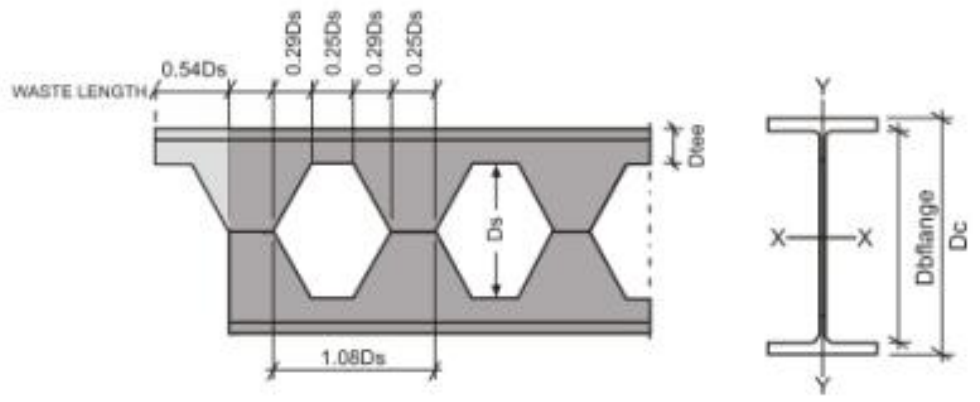

CASTELLATED SECTION

Fig. 1. Standardized ccastellated beam

This castellated beam was modeled in the finite element analysis, together with the column. Following the castellated process, the profiles of the beam for each type are W225x75 and W30x132, while the column profiles are adjusted to be H250x250 and W18x221 for the first two types and the last respectively. The castellated beam has properties $366.17 \mathrm{Mpa}$ and $433.76 \mathrm{Mpa}$ for yield and ultimate strength respectively. On the other hand, the column has 410.11 Mpa and 487.36 Mpa for yield and ultimate strength respectively.

\section{Reduced beam section (RBS)}

RBS consequently reduces stiffness of the beam and on the contrary, strengthens joint connection. In a RBS moment connection (Figure 2), portions of the beam flanges are selectively trimmed in the region adjacent to the beam-to-column connection. Yielding formation is intended to occur primarily within the reduced section of the beam. RBS connections are prequalified for use in special moment frame (SMF) and intermediate moment frame (IMF) systems within the limits of these provisions. 


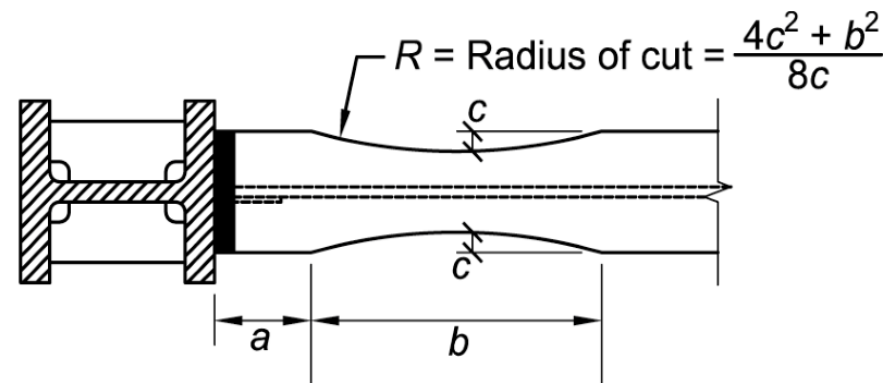

Fig. 2. Reduced beam section connection. (Prequalification limits)

Column sections and RBS dimension $a, b$ and $c$ (Figure 2) subject to the limits:

$$
\begin{aligned}
& 0.5 b_{b f} \leq a \leq 0.75 b_{b f} \\
& 0.65 d \leq b \leq 0.85 d \\
& 0.1 b_{b f} \leq c \leq 0.25 b_{b f}
\end{aligned}
$$

Where $b_{b f}$ is width of beam flange ( $\left.\mathrm{mm}\right), a$ is distance from face of column to the start of an RBS cut ( $\mathrm{mm}), b$ is length of an RBS cut $(\mathrm{mm})$ and $c$ is depth of cut at centre of the reduced beam section $(\mathrm{mm})$ and also $d$ is depth of beam $(\mathrm{mm})$. The protected zone shall be as defined for each prequalified connection. Unless specifically indicated in this standard, the protected zone of the beam shall be defined as the area from the face of the column flange to one-half of the beam depth beyond the plastic hinge. The protected zone shall meet the requirements of the AISC seismic provisions.

\subsection{Description of model RBS castellated beam}

Table 1 shows the description of steel material used for beam and column in each model. The specification of the table are models, spacing hole castellated beam from column, RBS length, cell diameter, cell spacing, and spacing RBS from column.

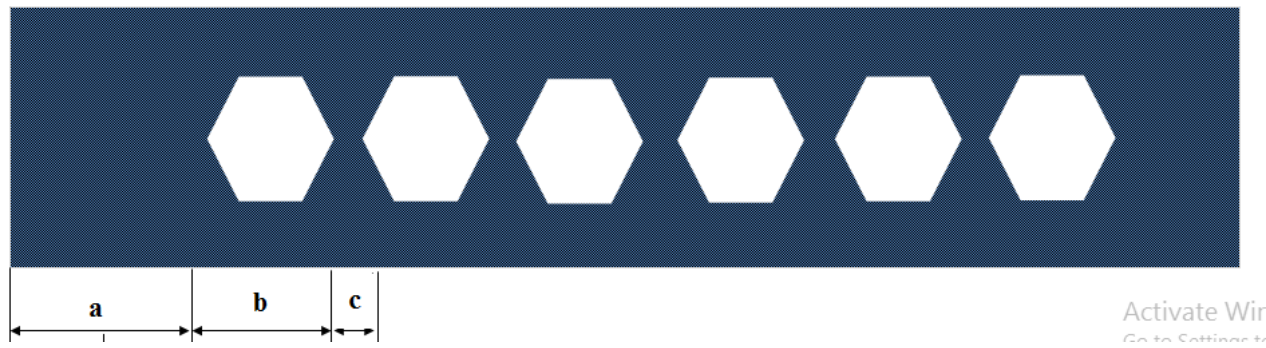

(a) Web castellated beam 


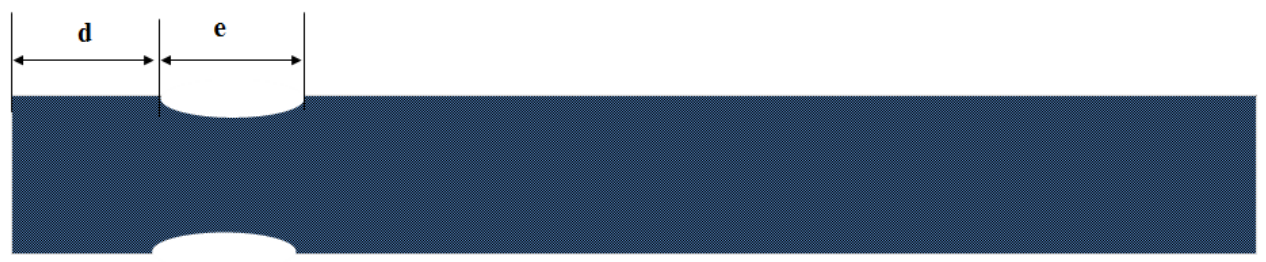

(b) Flange beam

Fig. 3. (a) Web castellated beam and (b) beam flange

Table 1. RBS and castellated beam specimen parameters

\begin{tabular}{|l|c|c|c|c|c|}
\hline Model & $\begin{array}{c}\text { Spacing Hole } \\
\text { CB from } \\
\text { column (mm) }\end{array}$ & $\begin{array}{c}\text { diameter } \\
\text { CB } \\
(\mathbf{m m})\end{array}$ & $\begin{array}{c}\text { spacing } \\
\text { hole CB } \\
\text { (mm) }\end{array}$ & $\begin{array}{c}\text { spacing RBS } \\
\text { from column } \\
\text { (mm) }\end{array}$ & $\begin{array}{c}\text { RBS } \\
\text { Length } \\
\text { (mm) }\end{array}$ \\
\hline WRBS-C & 225 & 125 & 125 & 38,5 & WRBS \\
\hline C RBS 1 & 280 & 125 & 125 & 38,5 & 280 \\
\hline C RBS 2 & 310 & 125 & 125 & 38,5 & 310 \\
\hline C RBS 3 & 350 & 125 & 125 & 38,5 & 350 \\
\hline
\end{tabular}

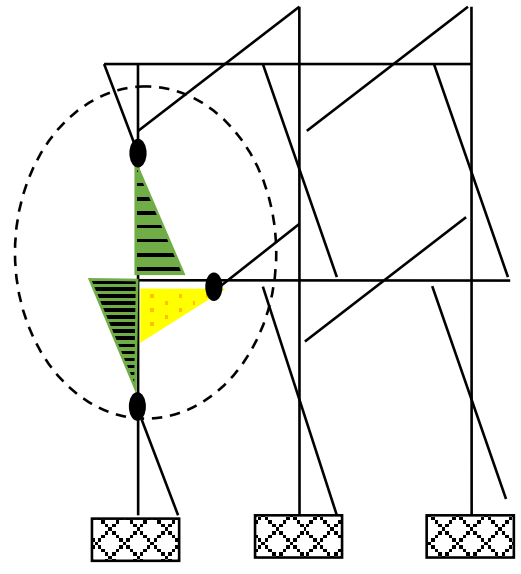

(a) Analysis model

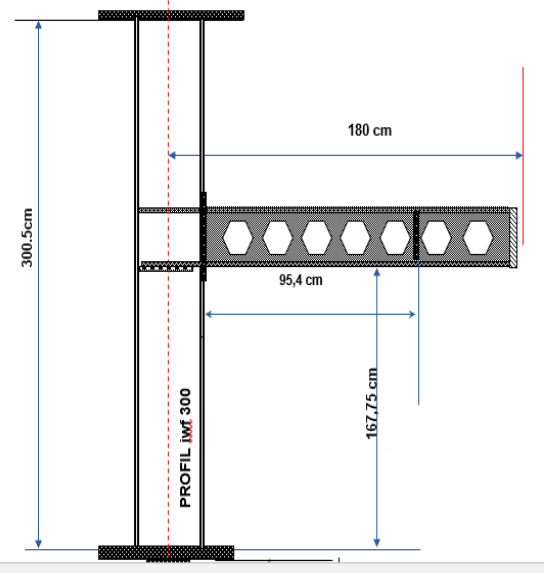

(b) Design of connection

Fig. 4. (a) Analysis model, (b) Design of connection 
From Figure 4(a), it can be seen the principal design of connection to meet hinge type and Figure 4(b) illustrates the design of connection used in the model.

\section{Result of modelling}

Based on analysis results, all models of RBS indicated crack on the flange, e.g. as shown on Figure 5. First model, WRBS-C, does not yield high stress concentration on its flange. However, 3 (there) other models, beam with RBS, demonstrate higher stress concentration on their flange section, including at top and bottom flange at the reduced beam section.

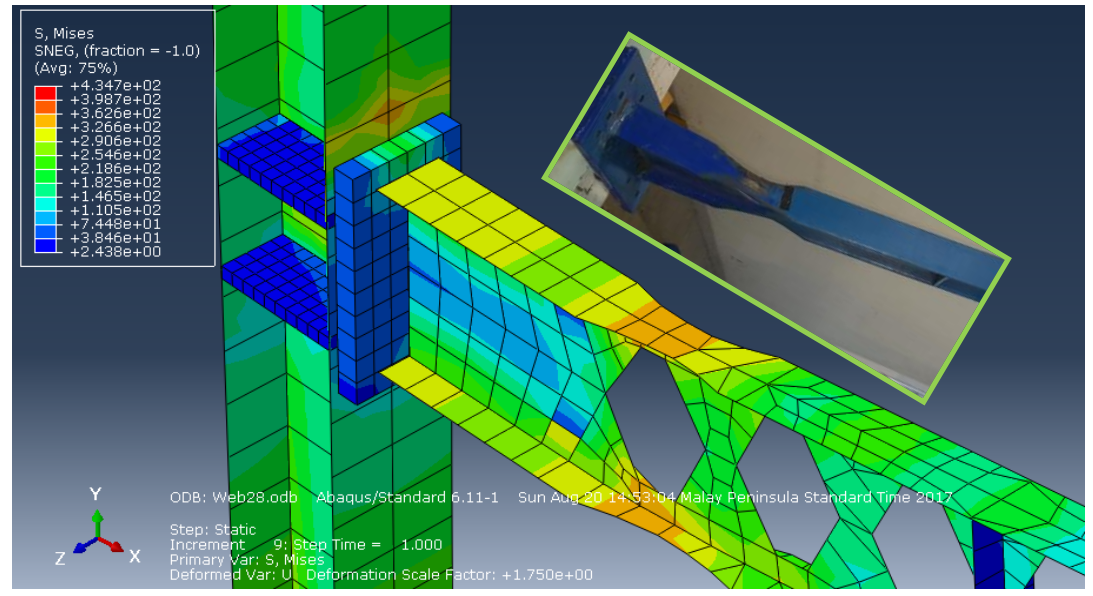

Fig. 5. Stress Distribution on RBS Castellated Beam

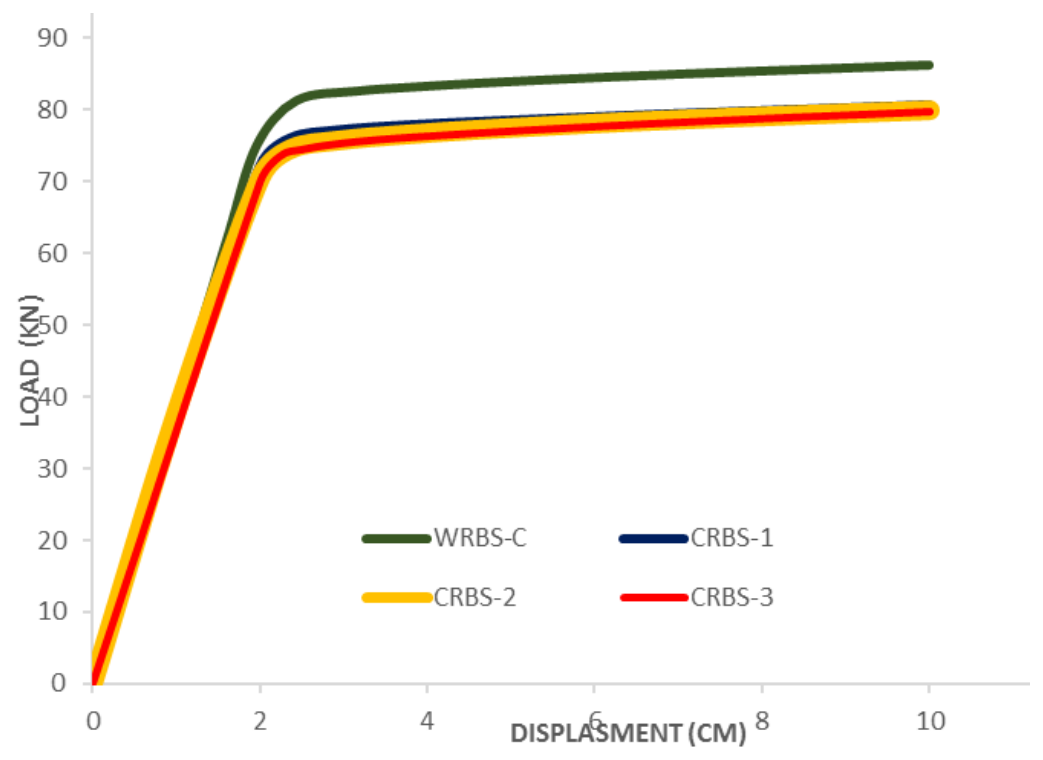

Fig. 6. Load - Displacement curve for monotonic loading 
Figure 6 demonstrates the comparison of all models in load-displacement relationship, where maximum displacement was set at $10 \mathrm{~cm}$. The highest maximum load carrying capacity from ABAQUS is WRBSC model i.e. $86.17 \mathrm{kN}$. Furthermore, the RBS models provided maximum load as follows, i.e. $80.63 \mathrm{kN}, 79.85 \mathrm{kN}$, and79.8 $\mathrm{kN}$ for CRBS-1, CRBS-2 and CRBS-3 respectively. There is approximately six to seven percent strength difference between non RBS and RBS castellated beam. In addition, at $28 \mathrm{~cm}$ from column face (CRBS-1), it performs best result model compared with CRBS-2 and CRBS-3.

\section{Conclusion}

Four models of castellated beam with one type of non RBS and three various types of RBS were conducted in this study. Beam profiles were modeled based on their standardized size on castellation process. Those sections and material properties were then designed on ABAQUS to obtain numerical analysis result. It can be implied that the difference of the maximum load between RBS and non RBS was not significant, since the RBS location was set as plastic hinge position where with regard to plastic phase in steel material, the yield modulus of both RBS and non RBS share approximately similar value. Therefore, RBS technique on castellated beam provides ability in resulting plastic moment far from the column face without significant loss of strength.

\section{References}

1. American Institute of steel Construction Prequalified Connection For Special and Intermediate Momen Frames for Seismic Aplications (AISC 358-10) Chicago. (2010)

2. Cheek-Ho Lee and Jae-Hoon Ki, Seismic Design of Reduced Beam Section (RBS) Steel Moment Connections with Bolted Web Attachment, College of Engineering (2004)

3. Chambers, J.J., Almudhafer, S. and Stenger F., Effect of Reduced Beam Section Frames Elements on Stiffness of Moment Frames, Journal of Structural Engineering, American Society of Civil Engineers, Vol. 129, No. 3. (2003)

4. Chen, S.J. and Chao, Y.C., Effect of Composite Action on Seismic Performance of Steel Moment Connections with Reduced Beam Sections, Joumal of Constructional Steel Research, Elsevier Science Publishers, Vol. 57. (2001)

5. Chen SJ, Yeh CH, Chu JM. Ductile steel beam-to-column connections for seismic resistance. Journal of Structural Engineering, ASCE;122(11) : 1292-9 (1996)

6. Mehrdad Memari, Hussam Mahmoud, Performance of Steel Moment Resisting Frame with RBS Connection Under Fire Loading, Journal Engineering Structure, Volume 75, page 126-138, Colorado State University, Fort Collins, CO, USA (2014)

7. Swati, A.K, Gaurang, V., Study of Steel Moment Connection with and without Reduced Beam Section, Case Studies in Structural Engineering, Volume 1, pages 26-31. (2014) 
8. Tonapa, S.R., Sandy, D., and Parung, H. "Behaviour of castellated beam-columns subjected to monotonic and cyclic loadings". International Journal of Engineering and Science Applications, pp 147-152. (2015).

9. Vahid, S.Z., Osman, S.A., and Khalim, A.R. "Monotonic and Cyclic Loading Simulation of Structural Steelwork Beam to Column Bolted Connections with Castellated Beam”. Journal of Engineering Science and Technology, pp 416-427. (2013).

10. Yousef Ashrafi, Behzad Rafezy and W. Paul Howson, Evaluation of the Performance of Reduced Beam Section (RBS) Connections in Steel Moment Frames Subjected to Cyclic Loading, Vol II WCE July 1 - 3, London. (2009) 